\title{
The Income Tax as Insurance: The Casualty Loss and Medical Expense Deductions and the Exclusion of Medical Insurance Premiums
}

\author{
Louis Kaplow $\dagger$
}

Whether personal income tax deductions are appropriate refinements to the concept of income or are unwarranted tax expenditures continues to be the subject of debate. The casualty loss and medical expense deductions are frequently justified on the ground that largely unavoidable losses or expenditures reduce one's ability to pay taxes. This Article reconsiders the question, taking into account the availability of private insurance, which is widespread for relevant losses in both areas. The author argues that when individuals can insure, the second level of insurance implicit in the casualty loss and medical expense deductions has undesirable effects on consumption choices and insurance decisions. In particular, individuals may be more exposed to losses because of tax deductions commonly believed to mitigate them. He concludes that, given the option, individuals would prefer a regime that eliminated the deductions and offered correspondingly lower tax rates.

\section{I}

\section{INTRODUCTION}

This Article examines the appropriate tax treatment of losses to one's property and person. ${ }^{1}$ The federal income tax provides offsets for

$\dagger$ Professor, Harvard Law School; Faculty Research Fellow, National Bureau of Economic Research. B.A. 1977, Northwestern University; A.M. 1981, J.D. 1981, Ph.D. 1987, Harvard University. I am grateful for comments from Stephen Choi, Erik Corwin, Steven Shavell, and participants in workshops at Yale and Harvard Law Schools and for support fron the John M. Olin Foundation.

1. This Article examines only personal losses: losses involving business and investment property are not considered, see infra notes $15 \& 17$, and personal injury losses are considered only with regard to medical costs, thereby excluding discussion of, notably, lost wages (which are not taxed because they are not ever earned). Also, the Article does not consider the tax treatment of tort recoveries or workers' compensation payments for personal injuries, which raise some similar issues but also others beyond the Article's scope. See infra note 64 . Some of these other issues are examined in T. Grifith, Should "Tax Norms" Be Abandoned? Rethinking Tax Policy Analysis and the Taxation of Personal Injury Recoveries (Oct. 2, 1991) (unpublished manuscript, on file with author). 
both: the former are allowed through the casualty loss deduction ${ }^{2}$ and the latter through the medical expense deduction and indirectly through the exclusion from income of employer-provided inedical insurance. ${ }^{3}$

For the inost part, arguinents about the appropriate base for the income tax have been grounded in appeals to the Haig-Simons concept of income $e^{4}$ or some substitute. From the underlying concept, cominentators derive the appropriate treatment of particular items using arguments about fidelity to the original definition. Stanley Surrey, who pioneered the tax expenditure movement embodying this approach, argued that personal deductions im the income tax are not appropriate refinements to the concept of income, but instead are improper subsidies that disproportionately benefit the wealthy. ${ }^{5}$ This position has been challenged, notably by William Andrews, who claims that the medical expense deduction, for example, can be justified on the ground that the cost of inedical treatment required to restore one's health reduces one's ability to pay taxes. ${ }^{6}$ Others, such as Mark Kelman, have in turn criticized this argument. ${ }^{7}$

The approach and conclusions of this Article differ from those of prior commentators. This Article does not involve an appeal to definitions. ${ }^{8}$ It reflects a view that debates about definitions cannot give meaningful guidance to policy unless informed by the objectives underlying

2. See I.R.C. §165(c)(3) (1988).

3. See I.R.C. $\S \S 106,213$ (1988). Some developed countries with similar tax systems employ parallel tax rules, while others do not. In Japan, individuals may deduct uninsured casualty losses and medical expenses above a floor, subject to a maximum; insurance premiums, however, are not deductible. See Tax Bureau, Ministry of FinanCe (JaPAN), AN OUTLINE of Japanese Taxes 1988, at 51 (1988). Germany allows deduction of health insurance premiums and "extraordinary financial burdens." See $1 \mathrm{H}$. GUMPEL, J. RUdDEN, K. RAMIN \& P. GUMPEL, World TAX SERIES: TAXATION IN THE FEDERAL RepUblic OF GeRMany II 2/2.4, 6/1.7b, 6/1.10a n.54 (2d ed. 1987). Canada allows a tax credit for medical expenses above a floor. See PrICE Waterhouse, INDIVIDUAL TAXES: A WORLDWIDE SUMMARY 49 (1990). South Korea allows a deduction for medical insurance premiums and for expenses above a floor, up to a maximum amount. See id. at 178. Notable exceptions include France and the United Kingdom, which do not permit deductions for casualty losses, medical expenses, or medieal insurance premiums. See id. at 106, 340.

4. See H. Simons, Personal Income Taxation 49-50 (1938); Haig, The Concept of Income-Economic and Legal Aspects, in THE FEDERAL INCOME TAX 1, 7 (R. Haig ed. 1921).

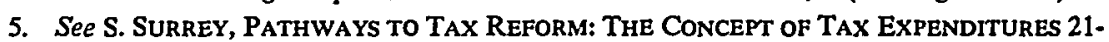
23, 193 (1973).

6. See Andrews, Personal Deductions in an Ideal Income Tax, 86 HARv. L. Rev. 309, 331-43 (1972); see also Bittker, Income Tax Deductions, Credits, and Subsidies for Personal Expenditures, 16 J.L. \& ECoN. 193, 196-99 (1973); Epstein, The Consumption and Loss of Personal Property Under the Internal Revenue Code, 23 STAN. L. REv. 454 (1971); Musgrave, In Defense of an Income Concept, 81 HARv. L. REv. 44, 56-57 (1967); Stephan, Federal Income Taxation and Human Capital, 70 VA. L. REv. 1357, 1385-1405 (1984).

7. See Kelman, Personal Deductions Revisited: Why They Fit Poorly in an "Ideal" Income Tax and Why They Fit Worse in a Far from Ideal World, 31 STAN. L. REv. 831, 858-79 (1979).

8. To be sure, rules of thumb, often embodied in concepts and definitions, can be useful in making everyday decisions. But when academic debate over important matters continues for decades, it is time to set aside aphorisms and substitute a more direct exploration. 
the definitions. ${ }^{9}$ Thus, the approach adopted here is to evaluate directly the effects of possible tax rules on individuals' well-being. This approach requires examining nidividuals' consumption choices and insurance decisions, both of which are inade before any loss occurs. The inclusion of insurance decisions in the analysis is particularly important. First, the most convincing rationales offered for the casualty loss and inedical expense deductions imphicitly appeal to notions relating to insurance. Second, insurance is widely available and frequently purchased both for medical expenses and major casualties (serious damage to homes and autoinobiles).

The analysis in this Article denionstrates that if individuals make informed, rational decisions concerning consumption and the purchase of insurance, ${ }^{10}$ deductions for casualty losses and inedical expenses are undesirable. An mcoine tax without these provisions that adjusted rates to nuaintain the same ex ante distribution of after-tax income would improve the circunistances of all individuals. ${ }^{11}$ The deductions constitute a form of subsidy, the amount of which depends upon one's consumption and insurance decisions, thereby distorting thein. For example, because the deductions cover ouly uninsured losses, individuals niay purchase less insurance than they would im the absence of the deductions, or even forgo insurance altogether, as additional purchases of private insurance require one to sacrifice the free partial insurance provided through the tax rules. Individuals would thus be inore exposed to the risk of losses as a result of tax deductions nominally designed to mitigate losses.

As the foregoing cominents indicate, a focus on the effects of tax rules rather than on their consistency with stipulated definitions inay

9. Thus, an income tax might be justified because it is better than the alternatives as a matter of efficiency and equity. For example, Andrews argues that the tax base should be defined in terms of what society means to redistribute. See Andrews, supra note 6 , at 326 . But what society means to redistribute can be determined only after stating the primciples from which redistributive policies are derived.

As Thomas Griffith emphasizes, a convincing resolution of many tax policy debates can only be achieved by stating explicitly one's normative benchmark-for example, utilitarian or Rawlsianand determining what treatment best achieves the corresponding objectives. See Griffith, Theories of Personal Deductions in the Income Tax, 40 HASTINGs L.J. 343 (1989). Grifith offers an intentionally oversimplified examination of the medical expense deduction solely for the purpose of illustrating how differences in objectives may translate imto different policy prescriptions. See id. at 385-94. While his illustration persuasively makes this point, his exclusion of ex ante considerations makes his account unconvincing with regard to what the appropriate treatment of medical expenses should be. Similar comments concerning the problems of deriving policy from definitions and another partial examination of the medical expense deduction can be found in Stiglitz \& Boskin, Impact of Recent Developments in Public Finance Theory on Public Policy Decisions, 67 AM. Econ. REV. 295 (1977).

10. For a discussion of these assumptions, see infra note 93 .

11. Thus, one need not adopt a particular view of distributive justice to resolve the issue as a matter of principle. See supra note 9. 
produce fresh insights and unexpected conclusions. This approach is significant not only for the tax provisions under consideration, which collectively involved an outlay equivalent of nearly $\$ 45$ billion in the last fiscal year, ${ }^{12}$ but also for the study of tax pohicy in general.

Another aspect of the present investigation deserves emphasis: its exphicit attention to uncertainty. Although the treatinent of economic uncertainty is one of the most important features of a tax system, this subject has received scant attention in the legal hiterature. ${ }^{13}$ The provisions for both casualty losses and medical expenses provide relief to individuals who experience unusually large losses that could not have been anticipated with certainty. It is this feature that turns out to be decisive in the analysis. Although only personal losses are considered here, ${ }^{14}$ this perspective is also relevant to investigating the appropriate tax treatinent of business and imvestment losses. ${ }^{15}$

The Article proceeds as follows. Parts II and III develop the analysis, moving from the effects of deductions on consumption choices to the simple and then more complex effects on insurance decisions. For convenience of exposition, Part II emphasizes the casualty loss deduction and Part III the medical expense deduction along with the exclusion from taxable incoine of employer-provided medical insurance, although much of the analysis in each Part is applicable to both deductions. ${ }^{16}$ Part IV discusses a variety of further issues, including the taxability of insurance proceeds, administrative factors, and distributional concerns. Part $\mathrm{V}$ offers a brief conclusion. Throughout, this Article emphasizes that all provisions of the tax code concerning casualty losses and medical expenditures-whether losses are deductible, whether insurance premiuns are excludable from taxable income, and whether insurance proceeds are taxable-must be examined simultaneously, as the effects of one provision inay offset or exacerbate those of another.

12. See infra text accompanying note 82. Also, reforms, including expansion, of the provisions for medical insurance and expenses are frequently proposed. See, e.g., Gray, Paying for Better Health Care: Would New Taxes Bleed the Patient?, 52 TAx Notes 742 (1991).

13. Some exceptions imclude Warren, Would a Consumption Tax Be Fairer Than an Income Tax?, 89 YALE L.J. 1081, 1101-09 (1980), and J. Strnad, Tax Depreciation and Risk 64107 (May 1991) (Social Science Working Paper 765, California Institute of Technology, Division of the Humanities and Social Sciences).

14. See supra note 1 .

15. The income tax allows deductions for bnsiness and investment losses, subject to various limitations. See infra note 17. For an exploration of some issues raised by uncertain gains and losses in profit-making endeavors, see L. Kaplow, Taxation and Risk Taking: A General Equilibrium Perspective (May 1991) (Discussion Paper No. 92, Program in Law and Economics, Harvard Law School).

16. The primary exception is that the exclusion for employer-provided medical insurance has no statutory analogue for casualty losses. It would, however, be possible to make casualty insurance premiums deductible, producing the same effects. 
II

\section{The Casualty Loss Deduction}

\section{A. An Illustration}

The casualty loss deduction is only relevant when the casualty affects an asset used for its owner's consumption; more general code provisions allow for the deductibility of busmess or investment losses. ${ }^{17}$ To examine the effect of the casualty loss deduction, consider a simple illustration. An individual contemplates buying a consumption good-a yacht. The yacht has a potential useful life of one period. There is a $10 \%$ chance that the yacht will be destroyed by a storm at the beginning of the period. ${ }^{18}$

The individual chooses from among the following alternatives:

Option 1 : Purchase a yacht for 100 . If it is destroyed by a storm, purchase another yacht for $100 .^{19}$

Option 2 : Purchase a yacht for 100 and insurance for 10.

Option 3 : Rent a yacht for its useful life at a rental of $110^{20}$

Option 4 : Purchase a xacht, which is like a yacht except that it is indestructible, for 110 .

Option 5 : Go to Europe for 110.

\section{B. Effect of the Casualty Loss Deduction on Consumption Choices}

To focus on behavioral effects uncomplicated by matters relating to insurance, begin with the case in which the individual is risk-neutralthat is, indifferent to risk. First, assume that there is either no income tax or an incone tax with no casualty loss deduction. The risk-neutral individual would value the first four options equally since each provides a period of yachting at an expected cost of 110 . The choice between these options and the European vacation will be determined by which yields greater utility. The individual's choice will be efficient, as there is no divergence between the private and social costs or benefits.

17. See I.R.C. $\S 165$ (c), (h) (1988). There are limits, however, including those on the deductibility of capital losses, see I.R.C. $\S \S 1211,1212$ (1988), and on the ability to carry over operating losses, see I.R.C. $\S 172$ (West Supp. 1991).

18. For convenience, assume that there will be no other storms during the period.

19. Given the structure of the example, it would be inore appropriate for the price of a yacht purchased after the storm to be 111.11, assuining all yachts including those not yet sold are subject to the same probability of destruction by the storm. (Otherwise, since the storm is assumed to be at the beginning of the period, individuals would simply wait until just after the tine during which the storm might strike to purchase yachts for 100.) With this adjustment, the appropriate insurance premium would be 11.11, the rental price would be 111.11, and the price for the xacht and the European vacation should be changed to 111.11. This complication is ignored to facilitate the exposition; the only effect on the analysis is to oversimplify slightly the measure of the extent of implicit insurance provided by a casualty loss deduction in this example.

20. The rental agency is assumed to be responsible for replacing the yacht if it is destroyed in a storm (such destruction having a $10 \%$ probability), so the agency will charge 110 rather than 100 . 
Next, consider an income tax with a marginal rate of $t$ and a full casualty loss deduction. ${ }^{21}$ The only effect is that option 1 is subsidized by $10 t$ : there is a $10 \%$ chance of losing 100 , such loss would produce a deduction worth $100 t$, and the individual, being risk-neutral, considers only the expected value. This leads to inefficient behavior if it induces the individual to choose option 1 when, for example, but for the deduction the European vacation would have been chosen because it yields greater utility. ${ }^{22}$ Thus, a tax system with no deduction (and that adjusted tax rates to offset distributional effects) would make individuals better off. ${ }^{23}$

The subsidy of option 1 will also induce the individual to choose it over options 2-4. As the example is now stated, this mducement is unimportant because the first four options produce identical utility at identical cost. In general, however, the resnlting preference for option 1 can be important. The different technologies (the xacht) and different methods of ownership (rental versus outright purchase) may entail different costs and produce different levels of utility. For example, the xacht may cost only $108^{24}$ or produce a more pleasurable experience or the rental may be inore convemient. As a result, the tendency of the subsidy to favor option 1 will distort these other choices as well.

\section{Effect of the Casualty Loss Deduction on Insurance Decisions}

Assume, more reahstically, that the individual is risk-averse. Moreover, to simphify the analysis, assume that the five options all would yield identical utility to a risk-neutral individual.

Consider the risk-averse individual's choice among the options when there is either no income tax or an incoine tax without a casualty loss

21. For simplicity, the $\$ 100$ exclusion, see I.R.C. $\$ 165($ h)(1) (1988), the $10 \%$ floor, see I.R.C. $\S 165(\mathrm{~h})(2)$ (1988), the requirement of itemization, see I.R.C. $\S \S 62,63$ (1988), and the $3 \%$ plaseout of personal deductions for lighl-income individuals, see I.R.C. $\S 68$ (West Supp. 1991), as well as the possibility that a casualty loss may affect one's marginal rate, see I.R.C. $\S 1$ (West Supp. 1991), are ignored.

22. More generally, when individuals can adjust the amount they spend on various consumption goods, sucl a subsidy will distort their beliavior.

23. Obviously, if there is no adjustment for the distributional effect, individuals can only be better off by being offered something for free that they may decline in whole or in part. The point of the distributional adjustment is to distimgnisl such an effect. Assume, for example, that eacl income class is given the clioice ex ante between the casualty loss deduction or slightly lower rates, and tliat the expected tax obligation in eacli regime would be the same. See Griffith, supra note 9, at 360-63; see also Andrews, supra note 6, at 338-39. Because individuals would unanimously prefer the latter, not allowing a deduction is Pareto superior to allowing one. Lower marginal tax rates may also reduce distortions in beliavior; this would furtlier increase the degree of preference for a system with no deduction. See Feldstein \& Friedman, Tax Subsidies, The Rational Demand for Insurance and the Health Care Crisis, 7 J. PuB. Econ. 155, 176 (1977).

24. At a marginal tax rate of $30 \%$, the subsidy would be worth 3 , making the expected cost of option 1-purcliasing a yachit without insuring-only 107. As a result, option 1 would be cliosen over the more efficient xacht, which costs 108. 
deduction. Such an individual would be indifferent among options 2-5each costs 110 for certain and produces, by assumption, identical utility. The individual, however, would strictly prefer any of these to option 1, which produces the same utility in consumption at the same expected cost, but involves the individual's bearing risk (the cost is 100 or 200 with probabilities of .9 and .1, respectively). The risk-averse individual will thus choose the "insurance" offered by options $2-5 ;{ }^{25}$ this choice will be efficient.

Next, consider again an income tax with marginal rate $t$ and a full casualty loss deduction. As before, the effect is to subsidize option 1, with the expected value of the subsidy being $10 t .{ }^{26}$ But option 1 is still risky, although to a lesser extent because the tax deduction acts as insurance covering a portion of the loss equal to $t$ : the individual now faces a loss of $100(1-t)$ with probability $10 \%$.

Thus, depending on the level of $t$ and the extent of the individual's risk aversion, either of two choices may be made: the individual inay, as in the case with no deduction, purchase one of options 2-5, or instead purchase option 1, bearing the portion of risk not mitigated by the casualty loss deduction. Whenever the latter choice is made, the result is inefficient: assuming taxes are adjusted to offset distributional effects, ${ }^{27}$ individuals are worse off because of the existence of the deduction.

The inefficiency in this instance arises not from the nature of the consumption or the technology, but from the fact that the individual bears risk. The subsidy induces the individual to forgo insurance, leading to the ironic result that the free partial insurance enbodied in the casualty loss deduction may encourage individuals to bear more risk than otherwise because they nuay select an aggregate level of protection against risk that is less than if the free partial insurance were not offered. $^{28}$ The explanation is simple: the more insurance the individual obtains, the more of the tax code's insurance must be forfeited. ${ }^{29}$ Because the tax code's insurance is free, one nust make a greater incremental econonic sacrifice than otherwise to obtain a more coinplete level

25. As this illustration demonstrates, "insurance" can take many forms: outright purchase (option 2), indirect purchase (option 3), choice of technology (option 4), or choice of a less risky activity (option 5 ).

26. The subsidy of $10 t$ arises because the tax system does not charge a premium for the implicit insurance it offers; an actuarially fair premium for coverage of $t$ on a 100 loss that has probability $10 \%$ would simply be $10 t$.

27. See supra note 23.

28. This possibility is noted briefly in W. Vickrey, Agenda for Progressive Taxation 60-62 (1947).

29. The deductions are only available for the portion of one's losses or expenses not covered by insurance. Even if this were not the case, choices that reduce the probability or magnitude of the loss would still involve sacrificing the tax code's imsurance. Moreover, the subtle distortions in insurance decisions that arise in the case involving moral hazard would still occur. See infra notes 59-60 and accompanying text. 
of insurance coverage. The asymmetry is that the tax code's partial insurance is subsidized but the alternatives, involving more complete protection against risk (broadly constrned to include options 2-5), are not.

Combining the effects noted im the preceding section with those here, the casualty loss deduction distorts choices of activity, technology, form of ownership, and exposure to risk. Note that this illustration confines private imsurance choices to all-or-nothing, whereas in fact some technologies or consumption choices may involve varymg levels of risk, and imdividuals may purchase insurance coverage that is incomplete. The primary reason individuals might purchase partial insurance coverage (aside from distortions caused by the tax system ${ }^{30}$ ) is to reduce the costs of moral hazard. Part III addresses moral hazard in its discussion of the medical expense deduction, and the conclusions are similar.

\section{The Conventional Argument for the Deduction}

The conventional argument takes an ex post perspective and considers whether it is appropriate to allow a deduction for an uninsured casualty loss. ${ }^{31}$ Implicitly, this approach considers only option 1. A horizontal equity argument is made: as between two imdividuals of identical adjusted gross income, each of whoin bought identical yachts and acquired no insurance, the one who suffers a casualty has less ability to pay taxes than the one who did not, so a deduction should be allowed to reflect this. ${ }^{32}$ This rationale is essentially equivalent to a straightforward insurance approach that mstead takes an ex ante perspective. ${ }^{33}$ If one wished to provide fully equal treatment to these precasualty equals, ${ }^{34}$ it would be necessary to make a transfer from the fortunate to the unfortunate that compensated completely for the latter's losses. This transfer is exactly what a complete insurance policy entered by all ex ante would accomplish-and exactly what rational individuals would have

30. In the absence of moral hazard, a loss deduction will generally lead individuals to purchase partial coverage (leaving them exposed to some of the loss when the effects of their partial coverage and the casualty loss deduction are combined) if the tax rate is moderate or low, but no insurance if the tax rate is above some critical value that depends on individuals' risk preferences and the extent of the loss. See L. Kaplow, Income Tax Deductions for Losses as Insurance (Feb. 1991) (Discussion Paper No. 83, Program in Law and Economics, Harvard Law School) (forthcoming AM. ECON. REV.).

31. See, e.g., sources cited supra note 6. This argument appears most often in connection with the medical expense deduction, which receives far greater attention. As noted in the introduction, the analysis of this Part is applicable to the medical expense deduction, and will not be repeated in Part III.

32. Goode notes the prevalence of this attitude with regard to the medical expense deduction. See R. Goode, The Individual INCOME TAX 157-58 (rev. ed. 1976).

33. See Kaplow, Horizontal Equity: Measures in Search of a Principle, 42 NAT'L TAX J. 139, 145-46 (1989).

34. The tax code's insurance only equalizes outcomes to the extent of $t$. 
purchased in the absence of a tax deduction. To accomplish this transfer through the tax systein imstead, a $100 \%$ credit ratler than a deduction would be necessary, witl taxes on each income class raised sufficiently to cover the costs. ${ }^{35}$

Once the connection between a tax break for casualty losses and insurance is made explicit, it is natural to adopt an ex ante perspective and consider directly the possibility that individuals may have purchased insurance or otherwise altered their beliavior to take account of the riskiness of their consumption decisions. ${ }^{36}$ A $100 \%$ credit for uninsured losses, by subsidizing option 1, would be inefficient and would not make available anything individuals could not lave obtained for theinselves. Moreover, as the next Part demonstrates, even if direct insurance (ratlier than alternative technologies or consumption choices) is what individuals desire, providing it through the tax system in the form of a deduction or credit results in other distortions that arise wlien one takes into account moral hazard. ${ }^{37}$

\section{III}

\section{The Medical Expense Deduction and the Exclusion of Medical Insurance Premiums}

\section{A. Issues for Analysis}

The medical expens $\mathrm{e}^{38}$ and casualty loss deductions are parallel provisions addressing parallel problems. ${ }^{39}$ Each provision allows individuals

35. Grifith notes the potential desirability of a $100 \%$ credit when discussing the medical expense deduction from a utilitarian perspective, although he does not make the imsurance comparison. See Griffith, supra note 9, at 394.

36. This perspective is considered briefly in $R$. GoodE, supra note 32 , at 154 , and in $W$. VICKREY, supra note 28 , at $60-62$.

37. When moral hazard is present, individuals optimally obtain partial insurance, so ex post there will be differences among ex ante equals. This raises the question of whether an ex ante or ex post equity perspective is appropriate. This Article employs the ex ante perspective because it selects a Pareto superior policy, assuming one makes ex ante distributional adjustments. This reinforces the criticism in Kaplow, supra note 33, of conventional horizontal equity notions: attaching any weight whatever to ex post horizontal equity violations in this instance would be unanimously rejected. Although it has been recognized that horizontal equity and utilitarianisin sometimes conflict, see, e.g., Stiglitz, Utilitarianism and Horizontal Equity: The Case for Random Taxation, $18 \mathrm{~J}$. PuB. ECON. I (1982), it is not thought that horizontal equity, as conventionally applied, might conflict with the Pareto principle.

38. See I.R.C. $\$ 213$ (1988). Because effects of fiexible benefit plans are similar, they will not be considered explicitly. The primary difference is that such plans cover expenses up to a ceiling (chosen by the individual), whereas the medical expense deduction covers all expenses above a fioor. The combination might result in some individuals being fnlly protected against small losses, not at all protected against additional losses through some range, and partially protected against greater losses-but at a decreasing rate, as large deductions would eventually reduce one's marginal tax rate.

39. Some of the analysis to follow is applicable to explicit government insurance, particularly Medicaid. See Cleeton, The Medical Uninsured: A Case of Market Failure?, 17 PuB. FIN. Q. 55 (1989). Just as some individuals might reduce or forgo casualty and hcalth insurance because a 
who itemize to take a deduction for uninsured losses above a floor representing a nontrivial percentage of adjusted gross income. ${ }^{40}$ As a result, the analysis is largely the same.

Two aspects of medical expenses not among the issues considered in Part II are emphasized here. First, the tax code, in addition to allowing a deduction for medical expenses, also allows many individuals an indirect deduction for medical insurance premiuns: employer-provided insurance is excluded from the measurement of an employee's gross mcome. ${ }^{41}$ Second, the analysis in Part II did not address moral hazardthe tendency of individuals to take less effort to control costs when some or all of their costs are borne by others, such as the insurer. The level of medical expenditures is typically thought to be determined by individual behavior both before an adverse event (smoking, taking up dangerous sports, or eating poorly, for example) and afterwards (frequency and duration of contact with the medical system, types of practitioners used, and diligence in adhering to prescribed treatment). Thus, it is common to emphasize moral hazard when considering medical care, ${ }^{42}$ although

fraction of uninsured losses are borne by the governnient through the tax system, so individuals may forgo health insurance-particularly for catastrophic events-because of Medicaid. This incentive wonld presumably be greatest for low- or moderate-inconie individuals with few assets. By forgoing insurance, they are likely to save money. In the event of a serious nedical problem, their sinall margin of incone and assets would qnickly be wiped out, at which time they would becoune eligible for Medicaid.

This argunent concerning the incentive effects of Medicaid is broadly consistent with empirical evidence on medical insurance patterns in the Umited States. Low- and moderate-income individuals are disproportionately represented among the tens of millious who are uninsured. See K. SWARTZ, The Medically Uninsured: Special Focus on Workers 4-5, 9-10 (1989); Moyer, A Revised Look at the Number of Uninsured Americans, HealTH AFF., Sumner 1989, at 102, 105-08; Pauly, Taxation, Health Insurance, and Market Failure in the Medical Economy, 24 J. ECON. LITERATURE 629,637 (1986). Moreover, firms with larger percentages of low-wage workers are less likely to offer insurance, and thus their enıployees are less likely to be insured. See Rossiter \& Taylor, Union Effects on the Provision of Health Insurance, 21 INDUS. REL. 167, 173 (1982). Even among those poor families that do have private health insurance, the proportion without a limit on the amount of hospital expenditures they might have to pay is approximately $20 \%$ higher than the national average. See Farley, Who Are the Underinsured?, 63 HEalTH \& Soc'y 476, 487-90 (1985). Finally, there is considerable turnover in the Medicaid population: in 1977, nearly 5 unillion individuals had Medicaid for part of the year and had no insurance (3.3 million) or other nisurance (1.6 million) for the renainder of the year. This high level of turnover suggests that at least soune individuals regard Medicaid as a readily available option in case they encounter large nedical expenses. See Wilensky \& Berk, Health Care, the Poor, and the Role of Medicaid, HeALTH AFF., Fall 1982, at 93, 94-95. A regime of conipulsory insurance-for example, through national health insurance-would not, of course, produce this sort of problen.

40. The floor is currently $7.5 \%$ for medical expenses, see I.R.C. $\S 213$ (a) (1988), and $10 \%$ for casualty losses, see I.R.C. $\$ 165(\mathrm{~h})(2)(1988)$. Other details not central to the analysis are again ignored. See supra note 21 .

41. I.R.C. $\$ 106$ (1988); see also infra note 48 (discussing deductibility of medical insurance preniums). A provision that is currently set to expire at the end of 1991 allows self-eniployed individuals to deduct $25 \%$ of nedieal insurance preniunis. See I.R.C. $\$ 162(l)(1)$ (West Supp. 1991).

42. Kelman points to the fact that illness is influenced by past behavior as a reason for denying 
moral hazard is surely relevant for casualty losses as well..$^{43}$

This Part will analyze only the issues that arise from the possible deductibility $^{44}$ of insurance premiums and from the consideration of moral hazard. A complete analysis of the casualty loss and medical expense deductions can be obtained by combining the relevant portions of Parts II and III.

\section{B. Analyzing the Different Tax Regimes}

This section examines four possible regimes, each partially reflected in current law. ${ }^{45}$ For the moment, it is assumed that, as under current law, msurance proceeds used to pay medical expenses are not taxable. ${ }^{46}$

Regime 1 : Premium not deductible, uninsured expenses not deductible. ${ }^{47}$

Regime 2 : Premium not deductible, uninsured expenses deductible. ${ }^{48}$

Regime 3 : Premium deductible, uninsured expenses not deductible. ${ }^{49}$ Regime 4 : Premium deductible, uninsured expenses deductible. ${ }^{50}$

Under regime 1, which corresponds to the situation considered mitially im Part II.B on casualty losses, individuals bear all of their losses and the full cost of any insurance. Assuming (throughout this section) that individuals are risk-averse, they would purchase insurance. Were it

a deduction for medical expenses, but his reasons for stressing this fact are largely unrelated to those offered here. Rather, he raises the point to emphasize that voluntariness, combined with the tax system's tendency not to tax psychic income arising from prior choices, undermmes Andrews' argument for allowing a deduction. See Kelman, supra note 7, at 863, 868-71. Kelman does not explicitly state the normative principle from which it follows that a deduction should not be permitted.

43. For example, before a storm hits, one can take more or fewer precautions to prevent damage to one's yacht and, after damage is done, more or less care in selecting who will perform the repairs. (Note that casualty losses are usually measured directly, by the loss incurred, while medical losses are measured by expenditures to correct them. One could, however, imagine valuing each in a different manner.)

44. For convenience, the discussion will refer to the deduction of premiums rather than to the employer's payment of such premiums being excluded from imcome.

45. The analysis will abstract from current law and consider each regime in its pure form-ignoring, for example, that a loss may be deductible only to the extent it exceeds a floor.

46. See I.R.C. $\S \S 104(\mathrm{a})(3), 105(\mathrm{~b})$ (1988). The option of taxing such proceeds is considered in Part IV.A.

47. This regime currently governs individuals either uneinployed or whose employers do not provide health insurance, who have expenses below the floor or do not itemize.

48. This regime currently governs individuals either unemployed or whose employers do not provide health insurance who itemize, with respect to expenses above the floor. While medical insurance premiuns are deductible, for most individuals who itemize (typieally middle and higher income individuals), the cost of health insurance would be mostly or totally under the floor. See $\mathrm{R}$. GOODE, supra note 32, at 159.

49. This regime currently governs employees with employer-provided insurance that covers losses that are below the floor or are not deductible because the individual does not itemize.

50. This regime currently governs employees with employer-provided insurance who itemize, with respect to expenses above the floor. 
not for moral hazard, they would, under regime 1 , purchase complete coverage. In the presence of moral hazard, however, they would purchase only partial coverage in order to maintam some incentive to control costs. ${ }^{51}$ This is the second-best optimum in that, given available information, any alternative, whether involving more or less coverage, leaves individuals worse off.

In regime 2, the deductibility of uninsured losses, as with the deductibility of casualty losses, is tantamount to free partial insurance. Because of moral hazard, this free insurance distorts incentives. ${ }^{52}$ Moreover, it affects imdividuals' insurance decisions. The most straightforward effect is that each imcrement to the level of private insurance coverage requires one to forgo some of the free insurance offered through the tax code. This imduces individuals to choose less coverage overall than they would have chosen under regime $1 . .^{53}$

There are, however, two countervailing effects, described more fully in the discussion of the fourth regime: the level of government insurance through the tax system may exceed the level of private insurance individuals would have purchased; and some of the moral hazard effect of private insurance is externalized to the government, which may induce individuals to purchase greater aggregate levels of coverage than otherwise. The tendency to purchase less insurance to qualify for more of the government's free imsurance will dominate when moral hazard is not very great. In such cases, individuals would purchase nearly complete coverage were it not for the deductibility of uminsured losses. (Thus, in the illustration in Part II, in which moral hazard was ignored, individuals purchased complete coverage when losses were not deductible, but might have forgone coverage if losses were deductible.)

To compare individual welfare in regimes 1 and 2 it is appropriate, as noted previously, to adjust taxes to remove any distributional effects. When this is done, it is clear that welfare is lower in regime 2: the different aggregate level of protection against risk chosen in regime $2^{54}$ could have been chosen in the undistorted system (regime 1) but was rejected because it yielded less utility.

51. See Shavell, On Moral Hazard and Insurance, 93 Q.J. EcoN. 541 (1979).

52. Kelman notes that if a medical expense deduction is to be allowed, it would be more appropriate to permit specified deductions for particular ailments, where the amount of the deduction does not depend on individuals' actual expenditures. See Kelman, supra note 7, at 876. His motivation is to separate the consumption dimension of some medical expenditures from their treatment aspect. Whatever the virtue of this objective, such an approach has the desirable feature that it avoids ex post moral hazard. See Pauly, supra note 39, at 642. Presumably, this is one reason that public and private health insurance schemes have recently moved toward reimbursing providers based on treatment categories.

53. See supra Part II.C.

54. By coincidence, for some individuals the two tendencies may precisely offset so that their welfare in regimes 1 and 2 would be equal. 
In reginie 3 , because insurance premiums are deductible but uninsured losses are not, insurance is subsidized. Thus, individuals purchase a greater level of coverage than they would otherwise prefer. ${ }^{55}$ As coinpared with regime 1 , they are purchasing protection against risk that is not worth the added social cost when one takes account of the increase ni inoral hazard, ${ }^{56}$ but this inefficient choice is nonetheless inade because of the subsidy. ${ }^{57}$

In regime 4 , in which both premiums and uninsured losses are deductible, it might appear that there is no distortion of the insurance decision $^{58}$ - that is, that the distortions in regimes 2 and 3 precisely offset. For each unit of protection, one pays a premiun. The unit of protection only effectively shields one against 1-t umits of the loss (because $t$

55. See Pauly, supra note 39 , at 641 . Farley and Wilensky estimated that a family paying the average amount of premiums (\$987) with no tax benefit and subject to the average tax rate (31\%) would spend an additional $\$ 132$ if the tax subsidy applied to the entire premium. See Farley \& Wilensky, Household Wealth and Health Insurance as Protection against Medical Risks, in HoRIzontal EQUity, UNCERTAINTY, AND ECONOMIC WELl-Being 323, 337 (M. David \& T. Smeeding eds. 1985). Feldstein and Friedman estimated large effects of the tax subsidy on the level of health insurance purchased (in particular, on coinsurance rates-the portion of expenses individuals would remain responsible to pay), implying large welfare losses. See Feldstein \& Friedman, supra note 23; see also Chernick, Holmer \& Weinberg, Tax Policy Toward Health Insurance and the Demand for Medical Services, 6 J. HEALTH ECON. 1 (1987) (arguing that elimination of exclusion for employer-provided health imsurance would reduce demand for it by $16 \%-27 \%$ and demand for medical services by $4 \%-6 \%$ ); Feldman \& Dowd, $A$ New Estimate of the Welfare Loss of Excess Health Insurance, 81 AM. ECON. REv. 297 (1991) (providing recent large estimates of welfare loss, but not deriving how much excess insurance may result from the tax system). Other studies are surveyed in Pauly, supra note 39, at 638, who indicates that, at the time of his writing, the tax subsidy was sufficiently large to make the after-tax cost of insurance protection negative for many workers (that is, the after-tax cost of premiums was less than the expected payments).

56. If the incentive to purchase insurance is insufficient due to other distortions, see, e.g., supra note 39 and infra note 93 , some subsidy of insurance may be desirable, although there is no reason for believing that the subsidy should take the form or have the magnitude of the current exclusion for medical insurance premiums. See Pauly, Optimal Public Subsidies of Nursing Home Insurance in the United States, 14 Geneva PAPERS ON RISK \& INS. 3 (1989) (arguing that replacing the Medicaid system with a system of long-term-care insurance subsidies would benefit both consumers and taxpayers).

57. That much employer-provided insurance covers $100 \%$ of very small losses illustrates this effect. For example, some dental policies cover only expenses up to $\$ 1000$. See Phelps, Tax Policy, Health Insurance, and Health Care, in MARKET Reforms IN HEALTH Care: CuRRENT Issues, New Directions, Strategic Decisions 198, 209 (J. Meyer ed. 1983). Given the moral hazard and administrative costs involved, combined with the small amount of risk, it seems plausible that such policies are a product of the tax system. See id. at 209-13; see also Pauly, supra note 39, at 644 . Group plans, most of which are employer-provided and thus subsidized by the exclusion of employer-paid premiums from income, are also far more likely than individual plans to have coverage for dental care, physician office visits, prescription drugs, and medieal equipment, while they are far less likely to have deductibles of more than $\$ 100$. See P. FARLEY \& U.S. DePT. OF Health \& Human Services, Pub. No. 3406, Private Health Insurance in the United STATES 46-47, 63-64 (1986). In addition, individuals may use flexible benefit plans to pay in full for small items not covered by their insurance or excluded by the deductible.

58. The distortion in choice of activity or technology discussed in Part II would still exist, as noted at the conclusion of this section. 
of the loss was otherwise covered by the tax system), but that unit of protection costs only 1-t because the premium is deductible.

This argument, however, is incomplete. First, regime 4 will be inefficient to the extent the level of partial insurance imphicit in the tax code, considered alone, exceeds the level individuals would have chosen in regime $1 .^{59}$ Second, regardless of whether the tax code's implicit insurance coverage exceeds the level individuals would otherwise select, the existence of implicit government insurance that does not entail charging a premiuin results in what might be called a two-stage moral liazard problem, ${ }^{60}$ considered briefly in the discussion of regime 2 . To understand this effect, note mitially tliat each mcrement of protection entails furtler moral hazard. This moral hazard, in turn, increases the aggregate expected loss, which is insured partially by private insurance and partially by the tax system through the deduction. Thus, the additional moral liazard increases the expected costs of botli insurance systems. For private insurance, this increase will be reflected in the individual's premium. But because the tax systein cliarges no premium, a component of the increased expected cost will not be taken into account by the individual. As a result, the level of aggregate coverage the individual would choose in this regime will tend to be higher than the level of private insurance the individual would have bought in regime 1 , in which the individual received the full benefit of insurance but bore the full cost. In regime 1 , the individual purcliased insurance coverage up to the point at which an infinitesimal increase in coverage produced a risk-spreading benefit just equal to the imcentive cost (reflected in the premium). Under regime 4, that same incremental mcrease produces the same risk-spreading benefit but at less cost to the individual. As a result, the regime is inefficient.

Thus, all regimes except regime $1-$ no deductibility of premiums or uninsured losses-involve distortions in the insurance decision. Moreover, all regimes except regime 1 involve subsidizing inedical expenditures, which distorts consuinption choices in the manner suggested by the discussion in Part II. For example, even if regime 4 did not affect the extent to which individuals purchased insurance to cover prospective health care costs, the effective price of health care would be reduced: direct expenditures are partially rebated through the tax system, as are premiums for insurance that will reimburse expenditures. ${ }^{61}$ In sum, the

59. This is much less likely now that the top marginal rates are near $30 \%$ than when top rates were $70 \%$ or even higher. (1991).

60. See Kaplow, Incentives and Government Relief for Risk, 4 J. RISK \& UNCERTAINTY 167

61. The exclusion for employer-provided medical insurance is viewed by some as one of the most important problems with the system of financing health care. See, e.g., Steuerle, The Case for a Tax Credit or Voucher for Providing Health Care to the Nonelderly-Part Four: The Poor Design of 
conclusion of Part II that a deduction for losses is inefficient continues to hold when one considers a wider array of regimes and takes into account how moral hazard affects individuals' insurance decisions.

\section{IV \\ DisCUSSION AND EXTENSIONS}

The preceding discussion considered whether losses or expenses should be deductible and whether insurance premiums should be deductible. This Part considers a range of issues that further illuminate this analysis. Section A examines the additional and related question of whether insurance proceeds should be taxable. Another perspective on the deductions for casualty losses and medical expenses is introduced in section $B$, which considers the possibility of taxing the miphicit gain taxpayers realize when a loss that might have occurred does not in fact occur. A central point in the analysis is that the tax deductions for casualty losses and medical expenses are profitably viewed as a form of imphicit insurance. Section C coinpares this implicit insurance with ordinary private insurance from an administrative perspective to see what can be learned from some notable differences in how these systems operate. Section $\mathbf{D}$ einphasizes how the approach offered here differs from that common in the hiterature, and examines distributional concerns that arguably are addressed by the casualty loss and medical expense deductions.

\section{A. Taxability of Insurance Proceeds}

The discussion in Parts II and III took as given the current rule that insurance proceeds that cover casualty losses or medical expenses typically are not taxable, unless they reimburse previously deducted anounts. ${ }^{62}$ Often this treatinent is said to be justified because, if the proceeds were taxable, there would be an offsetting deduction in any event. Given all the limits on the casualty loss and medical expense deductions, ${ }^{63}$ this is not true in many instances. More importantly for present

Current Tax Preferences for Employer-Provided Insurance, 52 TAx NoTES 1219 (1991). One prominent reformer proposed a refundable tax credit with an upper limit on qualifying premiums to eliminate the marginal subsidy to health insurance (and to provide equal benefits regardless of income or employment status). See Enthoven, $A$ New Proposal to Reform the Tax Treatment of Health Insurance, HEALTH AFF., Summer 1984, at 21; see also supra notes 55 \& 57 (presenting evidence of effects of tax subsidy on insurance coverage), infra Part IV.D and note 93 (addressing distributional concerns and imperfections in consumer choices).

62. See I.R.C. $\$ \S 104(\mathrm{a})(3), 105(\mathrm{~b})$ (1988) (accident and health insurance proceeds); I.R.C. $\S 123$ (1988) (insurance proceeds paid to compensate or reimburse for living expenses during loss of occupancy caused by casualty). If proceeds exceed the adjusted basis of an asset and are not reinvested (that is, if the nonrecognition rule of I.R.C. $\S 1033$ (1988) does not apply), the gain is taxable.

63. See, e.g., supra note 21 (enumerating limits on casualty deductions). 
purposes, however, one can hardly rely on this rationale to the extent the justification for the offsetting deductions is placed in question.

Instead, it is useful to emphasize the prior payment of an insurance premium and make an analogy to the notion of basis. ${ }^{64}$ Begin by recalling the first regime considered in Parts II and III: ${ }^{65}$ preiniums are not deductible, losses are not deductible, and insurance proceeds are not subject to tax. Now compare an alternative that differs only with respect to the treatment of insurance: premiums are deductible and proceeds are included in income. ${ }^{66}$ Both systems would be nondistorting with regard to an individual's ex ante decision to purchase actuarially fair insurance (that is, msurance for which the premium just equals the expected recovery under the policy). The former system fails to recognize gain when one receives a large payment and fails to allow a loss deduction when no payment is made (that is, when one has good luck, and thus in hindsight would rather not have purchased the insurance). The basis can be seen as the premium, and it, on average, just equals the proceeds. With the latter systein, because the premium is deducted, the basis is zero. As a result, neutrality would require taxing the receipt of proceeds. It would appear that individuals should be indifferent between these two systems.

To analyze this further, consider the case in which there is no moral hazard. ${ }^{67}$ With the former system, individuals purchase full insurance coverage. The occurrence of a loss does not produce any fluctuation in actual income or after-tax incoine. With the latter systein, the possibility of a loss means that even individuals purchasing full coverage experience a fluctuation in their after-tax income: when a loss occurs, their after-tax income is lower by the alnount of the imsurance proceeds (which equals the amount of the loss) times the tax rate. Thus, the latter scheme involves the individual's bearing soine risk in that the tax system effectively erases a fraction of the insurance policy (the fraction equaling the tax rate). In principle, individuals could gross up their level of insurance coverage to offset this effect. ${ }^{68}$ For exainple, if the tax rate were one-

64. See I.R.C. $\S \S 1011,1012$ (1988). Because the argument in this section depends on the prior payment of an msurance premium, it is inapplicable to tort and workers' compensation recoveries, which are excluded from income. See I.R.C. $\S 104(a)(1),(2)$ (1988).

65. One could also consider modifications to the other regimes, but this would yield few additional insights.

66. Except for the timing of the deduction for the premium-a complication ignored herethis is equivalent to a system that views the premium as an investment in a financial asset, with realization at the time proceeds are received or at the expiration of the policy.

67. It would be straightforward to demonstrate that the analysis also applies when individuals purchase partial insurance coverage because of moral hazard.

68. This possibility, as well as the close relationship between whether insurance proceeds should be taxed and whether premiums should be deductible, is noted by Daniel Halperin. See D. Halperin, Valuing Personal Consumption-Cost vs. Value and the Impact of Insurance 45-48 (1989) (unpublished manuscript, on file with author). He also suggests another perspective: individuals who purchase insurance along with an asset subject to casualty loss have, in effect, purchased a 
third, they could purchase coverage for $150 \%$ of their loss. After paying tax on the proceeds, they would be just whole. The premium would be $50 \%$ higher than with the former system, but since the entire premium is deductible, the after-tax cost of the premium would be the same as with the former system.

At this point, it appears that the latter regime, by allowing deductibility of premiuns and taxing insurance proceeds, results in a wash. To avoid the administrative costs of accounting for all this, it would be better simply to adopt a system that ignores imsurance altogether.

There are, however, some additional differences. The existence of progressive rates can make the latter system less generous because the average tax rate on the proceeds might exceed the rate applicable to the deduction of the premiuin; the net effect would be to tax, and thereby discourage, the purchase of imsurance. On the other hand, the latter system is more generous with regard to any load paid on the insurance policy (that is, the amoumt in excess of the expected recovery to cover costs of administering the policy), because the load is deductible. The above analysis suggests that this generosity would be undesirable, as it amounts to a subsidy for the insured activity (for example, yachting). ${ }^{69}$ Finally, the former systein may be preferable because the latter requires individuals to purchase insurance that depends on their future tax bracket, which may be uncertain and create additional incentive probleins, particularly with coverage that nominally exceeds $100 \% .^{70}$ In conclusion, a systein that ignores insurance rather than one that taxes proceeds and allows premiums to be deducted seeins preferable. ${ }^{71}$

different asset. The loss is the insurance company's, not theirs, and the proceeds can be seen as flowing to the seller of the replacement asset. See id. at 34-35, 39-40. Following the illustration in Part II, one might say that the insurance company is like a lessor that has promised to make an asset available regardless of whether a casualty occurs. The lessee suffers no casualty loss and receives no payments.

69. See W. VICKREY, supra note 28, at 61 . For medical insurance, the nature of the subsidy is less apparent in the case where moral hazard is insignificant. Yet the load is a real cost of the insurance; it is more efficient that it be fully taken into account when individuals make insurance deeisions. To the extent all individuals would acquire insurance, paying the same load, the distributional consequences would be insignificant, but there may be efficiency consequences if the level or type of insurance purchased depended on the after-tax cost of the load.

70. In the example with $150 \%$ coverage, if one's tax rate unexpectedly declined, one would stand to profit by having one's asset destroyed. This possibihity introduces another source of moral hazard, which in turn affeets the level of insurance coverage individuals would obtain. This problem and the other noted in the text might be mitigated if the amount to be paid under the insurance policy were to depend on one's actual tax bracket, determined ex post. Such a policy, however, would introduce an additional moral hazard element with regard to one's taxable income (for example, the timing of one's realizations of capital gains would affeet the amount of insurance coverage).

71. A system that taxed proceeds and did not allow premiums to be deducted would inefficiently discourage the purchase of insurance. 


\section{B. Exclusion of "Gains"}

Daniel Halperin, ${ }^{72}$ paralleling an earlier suggestion of William Vickrey, ${ }^{73}$ has argued that the casualty loss deduction is defective because it is asymmetric: it allows a deduction for losses but does not include in income what might be termed "casualty gains." The idea is that one purchases an asset only if its expected value equals or exceeds its price. If in the event of a casualty the asset's value would be less than the price paid, the purchaser at the time of purchase inust have expected that if there were no casualty the value of the asset would exceed the price paid. ${ }^{74}$ That is, when there is no casualty, one possesses an asset worth niore than what one paid. Thus, the argument goes, if casualty losses are deductible, casualty gains should be taxable.

To illustrate, consider the example in Part II involving the purchase of a yacht (option 1). When there is no storm, there is a casualty gain of 10: the individual secured an asset worth 110 - the cost of rental or other alternatives that guaranteed the ability to engage in yachting for the period-for a price of only 100. Taxing this gain of 10 at the rate $t$ yields a tax due of $10 t$, precisely offsettimg the subsidy previously identified as arising froin the deduction. ${ }^{75}$

Consider the relationship between the idea that casualty gains are excluded and the analysis here. ${ }^{76}$ View the yacht purchaser as consisting of two personalities: one is in the business of purchasing yachts to rent, and the other is the lessee and user of yachts. ${ }^{77}$ The former stands to have a profit of 10 if there is no storm, and a loss of 100 if there is (because the yacht must be replaced, to rent to the other personality). Standard, uncontroversial tax accounting for this business would show both the profit (the "casualty gain") and any casualty loss. The lessee/ user pays the lessor/purchaser the market rental, which is not deductible and thus results in no tax consequences, regardless of whether there is a

72. See D. Halperin, supra note 68 , at $25-28$.

73. See W. VICKREY, supra note 28 , at 61 .

74. The reasoning also applies to the medical expense deduction: good health ex post is better than the average level of health that wonld have been anticipated ex antc.

75. As presented in the text, the numbers do not fully add up because taxable income of 10 with probability .9 and a tax deduction of 100 with probability .1 leaves one with an expected (net) deduction of 1 , and thus an expected subsidy of $1 t$. But if one adjusted the examplc to be complete, as described in note 19 , the casualty gain would be 11.11 rather than 10 , so the (net) expected deduction and subsidy would be zero.

76. Although for many purposes Halperin adopts an ex ante perspective and often discusses the effect of tax provisions on the pnrchase of insurance, he does not systematically examinc the effects of different regimes as is done here; nor does he offer explicit criteria for evaluating the effects.

77. Since the example involves only one period, where the asset is fully expired at the completion, the issue of excluding imputed rent from the tax base does not arise. See D. BRADFORD \& U.S. Treasury TaX Policy StafF, Blueprints for Basic Tax Reform 89 (2d ed. 1984); R. GOODE, supra note 32, at 154-55. 
casualty. ${ }^{78}$ Arguably, therefore, the correct treatment of the single individual-the purchaser/user-should be the sum of the treatment of these two hypothetical personalities.

With regard to the activity choices discussed in Part II and the insurance choices addressed in Parts II and III, the effect of allowing the casualty loss deduction while taxing casualty gains appears to be largely the same as that of allowing no deduction and failing to tax gains. Because measuring gains (which involves assessing the ex ante probability of losses that did not occur during the tax year) would be administratively costly and often nearly impossible, ${ }^{79}$ as Halperin emphasizes, it seems preferable simply to disallow a deduction for casualty losses. Because the prospective gains and losses that are ignored accrue to the same individual, typical problems of tax arbitrage do not arise. $^{80}$

There remains, however, an important difference between a regime that ignores losses and gains and one that involves deducting losses and taxing gains: the latter amounts to compulsory partial insurance (to the extent of one's marginal tax rate) while the former does not. Thus, the latter regime is subject to the insurance distortion arguments presented in Part III.B addressed to a regime that allowed a casualty loss deduction and a deduction for insurance premiums (regime 4). ${ }^{81}$ First, if the marginal tax rate exceeds the level of insurance that otherwise would be optimal (recall that with moral hazard optimal insurance is partial), inefficient overinsurance would result. Second, as individuals purchase more private insurance, some of the moral hazard is externalized to the government and consequently ignored. Thus, in addition to administrative considerations, there is a conceptual basis for preferring a system

78. See supra note 68 .

79. See W. VICKREY, supra note 28 , at 61 . In addition to various assets used in different ways, one must also consider medical expenses. In all iustances, any attempt at valuation would inevitably involve predictable errors, which would remtroduce some asymmetry. Ignoring both losses and gains avoids the problem entirely. Such valuations are imphicit in insnrance contracts in that voluntarily paid premiums reflect expected losses, and thus imphicitly measure the casnalty gain. See infra notes 83-86 and accompanying text (discussing admimistrative differences between direct insurance and tax deductions).

80. Of course, with progressive rates, the gains and losses would not all enter at the same rate, and to the extent the individual could influence the timing of such gains and losses, some manipulation would be possible.

81. Regime 2 entailed a tendency to underinsure in aggregate because increasing one's level of private insurance involved forgoing some of the free insurance implicit in the tax code. With regime 4 , this problem was avoided because the deduction for the premiun on private insurance just offset this effect. For the regime that taxes casualty gains, the tax on casualty gains is in essence the insurance premium for the government's insurance, so the government insurance is not free. In all these regimes, however, one is subject to the more subtle distortions in insurance coverage that arise when moral hazard is present. 
that would allow no deduction rather than one that would allow a casualty deduction while taxing casualty gains.

\section{Administrative Differences Between Private Insurance and Implicit Insurance Through the Tax System}

The discussion in Parts II and III assuined that both private insurance and implicit government insurance through tax deductions were simple and costless to administer. Considering adıninistrative costs and practices further illuminates the question of the appropriate tax treatinent and the differences between private insurance and governinent insurance through tax deductions.

First, the existence of tax deductions for losses that inay also be partially insured results in duphication of effort. Second-perhaps in part because of such duplication, in part because the level of government insurance is often modest, and in part because of limited enforceinent resources-the government spends far less effort on claims administration than do private insurance coinpanies. A taxpayer simply writes a number on a tax return and receives a check (implicitly-in practice, a refund may be larger or the tax due inay be sinaller). Rarely will there be an audit, examination of receipts, or analysis of the nature of the expense. This is striking when one considers that the medical expense deduction involved an outlay equivalent exceeding $\$ 3$ billion for fiscal year 1991 and the exclusion of employer insurance payınents, adınittedly far less subject to abuse, exceeded $\$ 40$ billion. ${ }^{82}$

There are other, nore subtle differences. ${ }^{83}$ Notably, private insurance involves tailoring coverage and setting preiniums to account for 1noral hazard and activity choices. ${ }^{84}$ Thus, with inedical insurance, categories of expenditures inore subject to moral hazard have higher coinsurance rates (that is, individuals contribute a greater percentage of such costs). Casualty insurance is inore expensive for types of assets subject to greater risks. For exantple, auto collision and theft coverage is inore

82. Office of Management and Budget, Budget of the United States Government, FisCal YeAR 1991 app. at A-72 (1990).

83. Differences in administrative costs have other ramifications. For example, as discussed supra notes 69-71 and accompanying text, private insurance policies involve load charges that reflect real costs, whereas the administrative costs of implicit tax code insurance are not charged to the insured. Another cost difference is that the tax code's insurance is more comprehensive: as one enters a new activity, one need not write a separate insurance policy. For major casualties, however, such as those involving a home or car, the administrative cost is likely to be small relative to the stakes involved. Moreover, individuals may still obtain liability coverage, and casualty coverage would often be available in the same policy.

84. In addition, individuals with different risk preferences can choose different levels of insurance coverage. The tax system's insurance is at a stipulated level. Moreover, this rate is greater the higher is one's income, and individuals with little ineome receive no insurance through the tax system. Yet, for a given loss, risk aversion is thought to be greater for those with lower incomes. 
expensive for costlier cars, and fire insurance is more expensive for wooden structures. Althougl limits on administrative resources and a desire to keep the tax system relatively simple could explain why government definitions do not make sucl distimctions, ${ }^{85}$ this is unlikely. Instead, such distinctions are not made because the tax code does not purport to be involved in the insurance business. There is no legal basis for invoking incentive considerations to exclude or reimburse at a lower rate casualty losses and medical expenses tliat taxpayers actually incur. ${ }^{86}$

In addition, existing tax rules nuay influence efforts aimed at controlling costs of the inedical care system. Cost control efforts liave received increasmg attention from insurance companies and the government with respect to Medicaid and Medicare, and concerns for cost control liave been important in the expansion of Healtl Maintenance Organizations and otlıer innovations in the nuarketplace. Medical systenı cost control, however, does not have similar prominence on the agenda of the Internal Revenue Service or the tax-writing committees of Congress, despite the tens of billions in revenue cost incurred annually for medical care througl the tax system. ${ }^{87}$ Enployer-provided insurance is the hon's share of these costs, so the tax coffers niay benefit indirectly as a result of private cost control efforts. Nevertheless, the fact that a significant fraction of the benefit of such efforts accrues to the government rather than directly to the purchasers of insurance coverage blunts insurers' incentives to himit healtl care costs.

\section{Comments on the Literature and Distributional Concerns}

The preceding discussion indicated that allowing deductions for casualty losses and medical expenses distorts activity choices and insurance decisions. In particular, the implicit insurance offered through the tax code may result in individuals' securing less aggregate protection against risk than they would in the absence of the deductions. Given a choice, individuals would prefer a tax code without such deductions and with

85. The tax code's definition of "casualty" refers to losses "from fire, storm, shipwreck, or other casualty, or from theft." I.R.C. $\$ 165(c)(3)$ (1988). Interpretations of "other casualty" emphasize suddenness. The apparent attempt is to distinguish probabilistic, substantial decreases in value from gradual, anticipated declines-wear and tear-which should not be deductible because they are consumption. If one wished to appeal to definitions, one could simply note that probabilistic consumption is still consumption. For example, assume houses were destroyed by floods for certain once every 100 years rather than with probability $1 \%$ every year or through erosion by a certain $1 \%$ annually. Clearly, behavior will be distorted if the tax code allows deductions for any of these causes of decreased value.

86. There are some narrow statutory exceptions, such as that for cosmetic surgery. See I.R.C. \$ 213(d)(9) (West Supp. 1991). More generally, when marginal rates are relatively modest, as they are currently, incentive effects may be correspondingly low. Nevertheless, a $30 \%$ subsidy is hardly a trivial matter, and the level of the subsidy does not vary with the extent of the incentive probleun.

87. Tax expenditures for the exclusion and deduction of health insurance premiuns in 1982 constituted about $10 \%$ of private health insurance expenditures. See Pauly, supra note 39, at 638 . 
correspondingly lower rates. In principle, it would be possible to distribute the revenue savings in a inanner that made all taxpayers better off..$^{88}$

One noteworthy aspect of this Article's analysis is that, unlike most commentary on these issues, none of it requires "income" or "consuinption" to be defined. Instead, the discussion focuses exclusively on the plausible effects on behavior of alternative regimes. Any conclusions about tax policy that einerge depend on how one assesses these effects. After the analysis is coinplete, one could, for example, deem medical expenses to be "consumption" or not, but this would inerely restate one's conclusion in less straightforward terms. ${ }^{89}$ Moreover, it would reopen debate about what one really means by "incoine" or "consumption" without illuminating the underlying reasons for preferring one tax treatinent over another. ${ }^{90}$

The investigation here also differs from much of the literature by adopting an ex ante rather than an ex post perspective. Instead of focusing on whether one who has suffered a loss deserves more generous treatment than one who has not, it considers the situation prevailing at the time individuals make decisions that influence the likelihood and extent of their losses and the degree to which they will be coinpensated. This perspective is important for two reasons. First, ex post tax treatinent has important effects on ex ante behavior that are relevant in assessing various tax regimes. Second, the ex ante perspective is relevant to considerations of equity. In particular, througl their insurance decisions and activity choices, individuals may reduce or elininate their exposure to losses. There is good reason to view differently losses voluntarily borne

88. As a practical matter, this generally would not be possible. It would not be administratively feasible, for example, to identify which individuals at a given income level engage in more casualty-prone activities. That some individuals would be worse off as a result of such a tax reform is not necessarily an argument agamst it, as there is no obvious basis for suggesting that individuals who prefer more risky activities should be entitled to pay less taxes.

If the revenue savings were distributed to income groups not im proportion to their current benefits but rather more evenly, the effect would be progressive. The exclusion for medical insurance premiums and the medical expense deduction-the bulk of the revenue involved-favor wealthier families. See Feldstein \& Friedman, supra note 23, at 176 \& n. 43 .

89. In commenting on his argument that the medical expense deduction is justified as a refinement to the concept of income, Andrews states that his point involves "recognizing that the notion of consumption as a base for personal taxation may rationally be elaborated differently than it is for other purposes." Andrews, supra note 6, at 337. Once the term becomes a term of art, however, it serves only to communicate accepted understandings, not as a basis for resolving new problems, because any presumption that one may draw upon familiar applications of the term is rejected.

90. This point should not be understood as a claim that using definitions, as with income or consumption, is necessarily wrong. Reasoning from definitions, concepts, and other proxies is often useful. As emphasized in the introduction, howcver, the existence of continued controversy itself seems sufficient to justify examining foundations. See supra note 8 . How often and when this is appropriate cannot be stated simply. 
by individuals who accepted a gamble and would have benefited financially if they had experienced a more favorable outcome. ${ }^{91}$ Moreover, in the context examined here, all individuals would in principle choose to be governed by a regime without deductions if they could. ${ }^{92}$ It is not clear what principle of distributive justice would refuse to honor this choice. ${ }^{93}$

There is, however, an important reservation concerning distribution: What if individuals have ex ante differences beyond their control? One might imagine such differences to be insignificant for inost casualty losses, but there are important differences in inedical condition that affect one's future medical expenses. Even these differences would not raise inportant distributional concerns if all could purchase insurance at the same rates and adverse selection were not a serious problenn. ${ }^{94}$ Those having access to fairly comprehensive group inedical insurance through einployers or professional organizations inay face hittle difficulty in this respect.

If, instead, some individuals are unable to obtain medical insurance

91. This point is suggested in D. BRADFord, UNTANGLING THE INCOME TAX 168 (1986) and in Bittker, Comprehensive Income Taxation: A Response, 81 HARV. L. REv. 1032, 1035 (1968).

92. See also supra note 37 and accompanying text (discussing horizontal equity).

93. One could view differently losses that were "voluntarily" borne by individuals who made uninformed or irrational decisions to forgo insurance. A inoderate paternalistic perspective might favor attempting to produce the result such individuals would have achieved had they chosen properly from the standpoint of their own welfare. In this instance, compulsory insurance at the level informed individuals would have chosen is preferable to deductions for a number of reasons. First, it provides the right level of protection, rather than the partial protection involved in a loss deduction that depends on one's tax bracket, status with regard to itemizing, and the like. Sccond, it avoids distorting activity choices that influence the extent of expected losses and thus the level of insurance premiuns (if such activities can be observed by insurance companies and used in setting premiums). Moral hazard froin the insurance itself may be unavoidable. One danger of a coinpulsory scheme is in setting the level of required coverage too high - particularly if the scheme must, of necessity, apply to a large portion of individuals who are well-informed and thus would make sensible decisions if not compelled to act differently.

Another aspect of imperfect consumer choice may involve ex post decisions. For example, some individuals may be reluctant to seek inedical care because they underestimate its value. This may arise because mdividuals do not appreciate the value of treatment or because treatment-such as for substance abuse-may involve positive externalities. A subsidy may help offset such a tendency. Nevertheless, a subsidy may be incst important for lower cost, preventive expenses, which would be under the floor of the current deduction. Moreover, to the extent that the existence of a medical expense deduction (in contrast to the exclusion for employer-provided insurance) discourages the purchase of imsurance, it might be seen as less desirable than suggested by the discussion in the text. Finally, an optimal subsidy scheme would presumably be directed to particular actions for which individuals underestimate value rather than broad categories of expenditure, and it would not offer greater benefits to the wealthy while excluding the poor and unemployed or self-employed (who now receive only a $25 \%$ deduction, see supra note 41 ).

94. It is not apparent that these are significant practical problems for inedieal insurance markets. For a discussion of insurer practices making adverse selection less likely, see Pauly, supra note 39, at 649-54. As he suggests, if the tax subsidy were removed, employers might offer a greater range of choices to employces, which could inake adverse selection inore serious than it currently is. Some believe that adverse selection would be a serions problem, but find the exclusion for insurance premiums an imefficient and inequitable solution. See, e.g., Enthoven, supra note 61, at 24, 29. 
except at very high rates because innate observable factors indicate that they are more prone to health problems, ${ }^{95}$ one may wish to take this into account in determining the appropriate distribution of income, and thus in determining the appropriate tax base. To avoid distorting insurance and other decisions of such individuals, it would generally be more efficient to offer direct subsidies or, if through the tax system, special deductions or credits that depend on status rather than actual events. Thus, for example, an additional tax deduction for the blind might be preferred to subsidizing particular purchases they inake. ${ }^{96}$ If such alternatives were too administratively costly and if innate health differences were substantial, one might choose to allow a medical expense deduction and a deduction for medical insurance preiniuins (particularly for nonemployer-provided insurance, where premium diffcrences would be the greatest) as a second-best alternative. Yet it might be preferable to pursue other health policies, such as insurance taxes and subsidies ${ }^{97}$ or national health insurance. ${ }^{98}$

\section{V \\ CONCLUSION}

This investigation has considered many aspects of the casualty loss and medical expense deductions. The perspective adopted here emphasizes that both deductions are, im essence, an odd sort of free, partial, quasi-coinpulsory insurance: for no explicit premium (except ligher taxes generally), some individuals (those wlio itemize) receive partial

95. In practice, it will often be difficult to determine whether a particular health risk is attributable to innate factors or prior voluntary choices, as einphasized by Kelman, supra notc 7, at 863,868 . For example, a middle-aged individual may face high medical insurance costs because of a life of smoking or poor nutritional habits.

96. See supra note 52.

97. Cf. Crocker \& Snow, A Simple Tax Structure for Competitive Equilibrium and Redistribution in Insurance Markets with Asymmetric Information, 51 S. ECoN. J. 1142 (1985) (arguing that even if the government cannot determine which insurance purchasers are subject to Inore risk, it may tax and subsidize different types of insurance policies to effect redistribution among groups subject to different risks).

98. By analogy, the case for an income tax to reduce variations in labor income arising from uncertainty that is anticipated is relatively weak, see L. Kaplow, A Note on Taxation as Social Insurance for Uncertain Labor Income (Feb. 1991) (Discussion Paper No. 84, Prograin in Law and Economics, Harvard Law School), while that for reducing variations in future labor income arising from unineasurable innate differences in ability stands independently, see Stern, Optimum Taxation with Errors in Administration, 17 J. PuB. EcoN. 181 (1982). The argument in the context of medical expenses is, however, inore precarious. Individuals with poorer innate health will face substantially higher insurance premiums only if insurance companies can determine at modest cost who such individuals are. But if this determination is in fact feasible, there is less of a case for using inedical expense deductions for uninsured expenses and other indirect policies rather than direct subsidies to benefit such individuals. Cf. Crocker \& Snow, The Efficiency Effects of Categorical Discrimination in the Insurance Industry, $94 \mathrm{~J}$. POL. ECON. 321 (1986) (demonstrating that it is more efficient for governinent to allow categorical discrimination supplemented by direct redistribution than to forbid categorical discrimination when the cost of categorization is sufficiently low). 
coverage (for losses above a floor) at a level equaling their tax rate (and thus higher for the more wealthy) for qualifying losses (with privately insured losses not qualifying). Focusing on individuals' ex ante decisions, the effect of these deductions is to distort behavior. Most obviously, activities are subsidized to an extent that increases with the risk of loss involved. Moreover, msurance decisions are distorted. One possibility is that individuals might reduce their coverage or forgo insurance entirely, in order that they will not sacrifice the free partial insurance offered by the tax system. In such cases, individuals bear more risk as a result of their being offered some free insurance. More subtle distortions that take into account moral hazard and its effect on insurance coverage were also considered.

The approach adopted here differs from most of the previous literature on these personal deductions by focusing entirely on the effects of various regimes on behavior and how these effects might be evaluated, ignoring the perplexing questions of how "income" and "consumption" should be defined. Moreover, it illustrates the need to consider simultaneously whether losses or expenses are deductible, premiums are deductible, insurance proceeds are taxable, and imiphicit gains are taxable, as changes in one provision may offset or exacerbate the effects of another.

This investigation, however, has one important element im common with much of the prior hiterature: it takes an ideal perspective. That is, the analysis considers what deductions should be permitted in an ideal income tax, abstracting from many administrative considerations and ignoring second-best coinphications, such as those pertaining to the medical system. Moreover, the discussion of individual behavior was only occasionally supported by empirical evidence concerning the magnitude of effects. ${ }^{99}$ As a result, the hypothesized inefficiency of the casualty loss

99. The primary reason these effects may not be substantial is the currently low (by historical standards) marginal tax rates. For example, with a $30 \%$ marginal tax rate, a deduction may be insufficient to induce many individuals to reduce their insurance coverage very significantly. By contrast, when marginal rates were $70 \%$, large effects were more likely. A $30 \%$ rate still creates a substantial disincentive to reduce the level of one's losses. Moreover, even at a $30 \%$ rate, the exclusion of medical insurance premiums may have a significant effect on the coverage imdividuals purchase, as reflected in the breadth of coverage. See supra note 57.

Ultimately, to the extent effects are small because of low marginal tax rates or the fact that many individuals do not itemize, any justification for the deductions is correspondingly reduced. In particular, if one favored the deductions as fall-back insurance for lower-income individuals, then low marginal rates (zero for the poor) combined with the fact that few lower-income individuals itemize may be decisive considerations against the provisions, at least in anything like their current form. (That lower-income imdividuals are less familiar with tax rules and thus less likely to respond to the incentives they create also would be of hittle relevance; it is rational for such individuals to know little of the casualty and medical deductions since they are untikely to benefit significantly from them in any event.) Conversely, much of the benefit of the deductions is concentrated on a modest portion of taxpayers: those in upper brackets, who itemize, and who are most likely to experience large uninsnred losses because of the nature of their activities and their decisions not to insure. 
and medical expense deductions and the exclusion of medical insurance premiums is an important but not decisive consideration in assessing reform of these provisions. It should be noted, however, that the existing rules are unlikely to be among the better policy responses to problems with the medical system and imperfections regarding insurance purchases. ${ }^{100}$

100. See, e.g., supra Part IV.C-D, and notes 39, 88, 93 \& 98. Whether superior alternative policies are politically feasible is not considered. 